\title{
SNAKE LINE ANALYSIS FOR LAHAR FLOW WARNING SYSTEM (CASE STUDY IN PUTIH RIVER, MOUNT MERAPI)
}

\author{
Nina Yulinsa \\ Large Basin River Organization of Serayu Opak, Yogyakarta, INDONESIA \\ bunda_youn@yahoo.com
}

\begin{abstract}
Lahar flow in the region of Mount Merapi after an eruption of 2010 is still considered potentially to happen and threat the region along the river from the upstream. The development of warning criteria against the potential occurrence of lahar flow is a thing that should be done continuously to accommodate dynamics data availability (rainfall data and lahar flow occurrence data), although with limited data. This study aims to develop lahar warning system applying snake line as a rain phenomenon in Putih catchment area which will affect the occurrence of lahar flow and to evaluate the success rate of snake line for deciding the warning system. This study used the main reference from Guidelines for Development of Warning and Evacuation System against Sediment Disasters in Developing Countries released by Ministry of Land, Infrastructure and Transport Infrastructure Development Institute - Japan (2004). This research was conducted through several stages, i.e. secondary data collection in the form of rainfall data, lahar flow occurrence data, making correlation graph between rainfall intensity and working rainfall, determination of critical line, warning line and evacuation line. The results show that standard rainfall for warning and evacuation alert in Putih River are 22 $\mathrm{mm}$, and $49 \mathrm{~mm}$, respectively. The accuracy of warning criteria and the evacuation criteria against snake line for warning line is $30 \%$, evacuation line is $61 \%$ and the critical line is $83 \%$. The behavior of snake line that indicates lahar flow occurrence in Putih River forming an angle of $40^{\circ}$ up to $45^{\circ}$.
\end{abstract}

Keywords: lahar flow, warning criteria, critical line, snake line, working rainfall

\section{INTRODUCTION}

Mount Merapi Eruption in 2010 produced 140 million $\mathrm{m}^{3}$ of sediment at the top of Merapi. The deposited sediment potentially causes lahar flow which will continue flowing during rain with certain intensity and duration and when there is still sediment at the top of Merapi. Putih River experienced the most lahar occurrence among other rivers, thus it faced the most severe damage and loss. The biggest damage was the collapse of national road connecting Yogyakarta and Magelang Regency at Jumoyo Village which disturbed transportation and economic cycle. Besides the physical loss, the lahar flow also caused death casualties. To reduce the loss of lives, it is necessary to develop criteria for early warning of the lahar flow potential.

The purpose of this research is to determine the criteria of early warning signals considering rainfall characteristics in the catchment area of Putih River affecting lahar flow occurrence which is expressed by "snake line" and to evaluate the success rate of snake line as the determinant of warning actions. Development of lahar flow early warning system on the slopes of Merapi, especially in Putih River is expected to give a recommendation for government policy in making decision when lahar flow occur.

\section{SETTING OF STANDARD RAINFALL FOR WARNING AND EVACUATION}

\subsection{Rain Series, Continuous Rainfall (RC), Antecedent Rainfall (RA)}

Rain series is a continuous rainfall that is isolated by the absence of rain for 24 hours or more, both before and after occurrence (see Figure 1). Working rainfall is cumulative rainfall influenced by antecedent rainfall calculation. Antecedent working rainfall (RWA) is the sum of all antecedent rainfall.

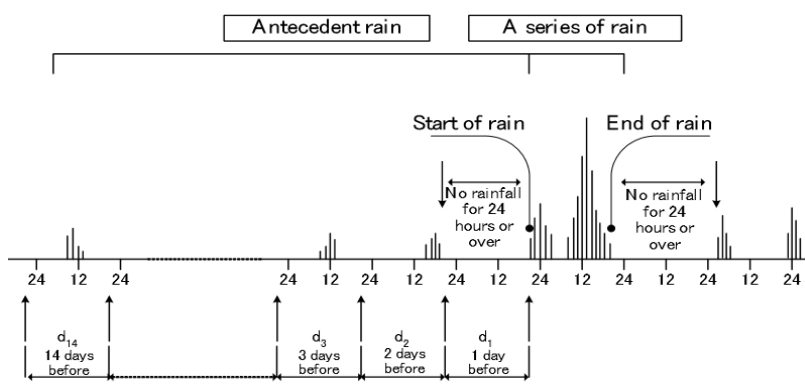

Figure 1. Rain series and antecedent rainfall concept (Ministry of Land, Infrastructure, and Transport (MLIT), 2004). 
$R W A=\alpha_{1} d_{1}+\alpha_{2} d_{2}+\ldots+\alpha_{14} d_{14}=\sum_{t=1}^{14} \alpha_{t} d_{t}$

$\alpha_{t}=0,5^{t / T}$

$$
R W A=0,25 \times d_{2}+0,125 \times d_{3}+0,0625 \times d_{4}+\ldots
$$

$R W=$ Cumulative Rain $+R W A$

Where $R W A$ is antecedent working rainfall $(\mathrm{mm}), \alpha_{t}$ is deduction coefficient " $t$ " days before, $d_{t}$ is antecedent rainfall " $\mathrm{t}$ " days before $(\mathrm{mm})$, " $\mathrm{t}$ " is time before the rainfall (day), $\mathrm{T}$ is half time $($ day $)=1$ day $($ Method $\mathrm{A})$, $R W$ is working rainfall $(\mathrm{mm})$, and $R W A$ is antecedent working rainfall $(\mathrm{mm})$.

2.2 Determining Critical Line, Warning Line, Evacuation Line, and Snake Line using the A Method

Critical Line (CL) is the boundary line drawn between rainfall events either causing a lahar flow or noncausing lahar flow. Maximum rainfall from hourly rainfall (RH1M) from the line is drawn horizontally then being intersected with $\mathrm{CL}$ to get $\mathrm{R} 2$, in which the vertical line serves as the evacuation line (EL). The evacuation line extends a bit to the left as much as RH2M-RH1M in which RH2M is the maximum rainfall from bi-hourly rainfall resulted in the warning line (WL), and R1 as the triggering rainfall for disaster signals. Snake line is a line showing the changes of cumulative rainfall and rainfall intensity as shown in Figure 2.

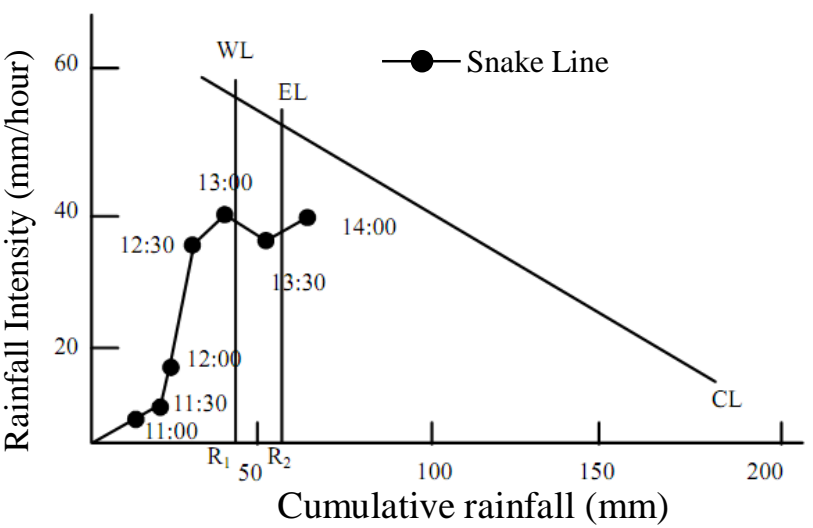

Figure 2. Drawing Snake Line.

\section{PREDICTION METHOD OF OCCURRENCE OF SEDIMENT DISASTERS}

The rainfall data from 3 rain station in the catchment area of Putih River was collected. Gunung Maron Station is located between coordinates of $110^{\circ} 23^{\prime} 34.5^{\prime \prime}$ EL and $07^{\circ} 33^{\prime} 56.8^{\prime \prime} \mathrm{SL}$, on the altitude of $960 \mathrm{~m}$ from Sabo Office (see Figure 3). PU-D2 Station is located between coordinates of $110^{\circ} 22^{\circ} 8.09^{\prime \prime} \mathrm{EL}$ and $07^{\circ}$ 34 '4.05" SL with an altitude of 737 m from UGM. Ngepos Station is located between coordinates of $110^{\circ}$ $25^{\prime} 50^{\prime \prime} \mathrm{EL}$ and $07^{\circ} 35^{\prime} 11^{\prime \prime} \mathrm{SL}$ with an altitude of 670 $\mathrm{m}$ from Sabo Office. The used data were the rainfall data after the Merapi eruption within 2010 -2011. Lahar flow occurrences data were obtained from Sabo Office Observation located in Mranggen Check Dam with coordinates of $110^{\circ} 21^{\prime} 43.2^{\prime \prime} \mathrm{EL}$ and $07^{\circ} 34^{\prime} 51.1^{\prime \prime} \mathrm{SL}$ (Ministry of Public Works, 2012). Newspaper article and data from the internet were collected to support data from Mranggen Check Dam. The data availability of each rain station can be seen in Table 1 .

Table 1. Data Availability

\begin{tabular}{|c|c|c|c|c|}
\hline \multirow{2}{*}{$\begin{array}{l}\text { Station } \\
\text { Name }\end{array}$} & \multicolumn{2}{|c|}{ Rainfall Data } & \multirow[b]{2}{*}{ Note } & \multirow{2}{*}{$\begin{array}{l}\text { Lahar Flow } \\
\text { Occurrence } \\
\text { Data }\end{array}$} \\
\hline & Start & Finished & & \\
\hline Gunung & $01 / 10$ & Year & Damaged & \multirow{5}{*}{$\begin{array}{l}\text { November } \\
2010 \text { s/d } \\
\text { February } \\
2012\end{array}$} \\
\hline Maron & $/ 2011$ & 2012 & $\begin{array}{l}\text { during } \\
\text { eruption }\end{array}$ & \\
\hline PU-D? & $22 / 11$ & Year & New & \\
\hline PU-D2 & $/ 2011$ & 2012 & Station & \\
\hline Ngepos & $\begin{array}{l}01 / 10 \\
/ 2011\end{array}$ & $\begin{array}{l}\text { April } \\
2011\end{array}$ & $\begin{array}{l}\text { Disconti } \\
\text { nued }\end{array}$ & \\
\hline
\end{tabular}

The following steps explain how to establish warning and evacuation line from rainfall data.

a) Determining rain series for analysis

b) Calculation of working rainfall (RW) and antecedent working rainfall (RWA)

c) Calculation of maximum rainfall from bi-hourly rainfall (RH2M) and maximum rainfall from hourly rainfall (RH1M)

d) Graphics drawing of the relationships between rainfall intensity and working rainfall

e) Determining Warning Line, Critical Line, Evacuation Line

f) Drawing Snake Line

g) Evaluating the Snake Line towards rainfall standard for establishing warning and evacuation. 


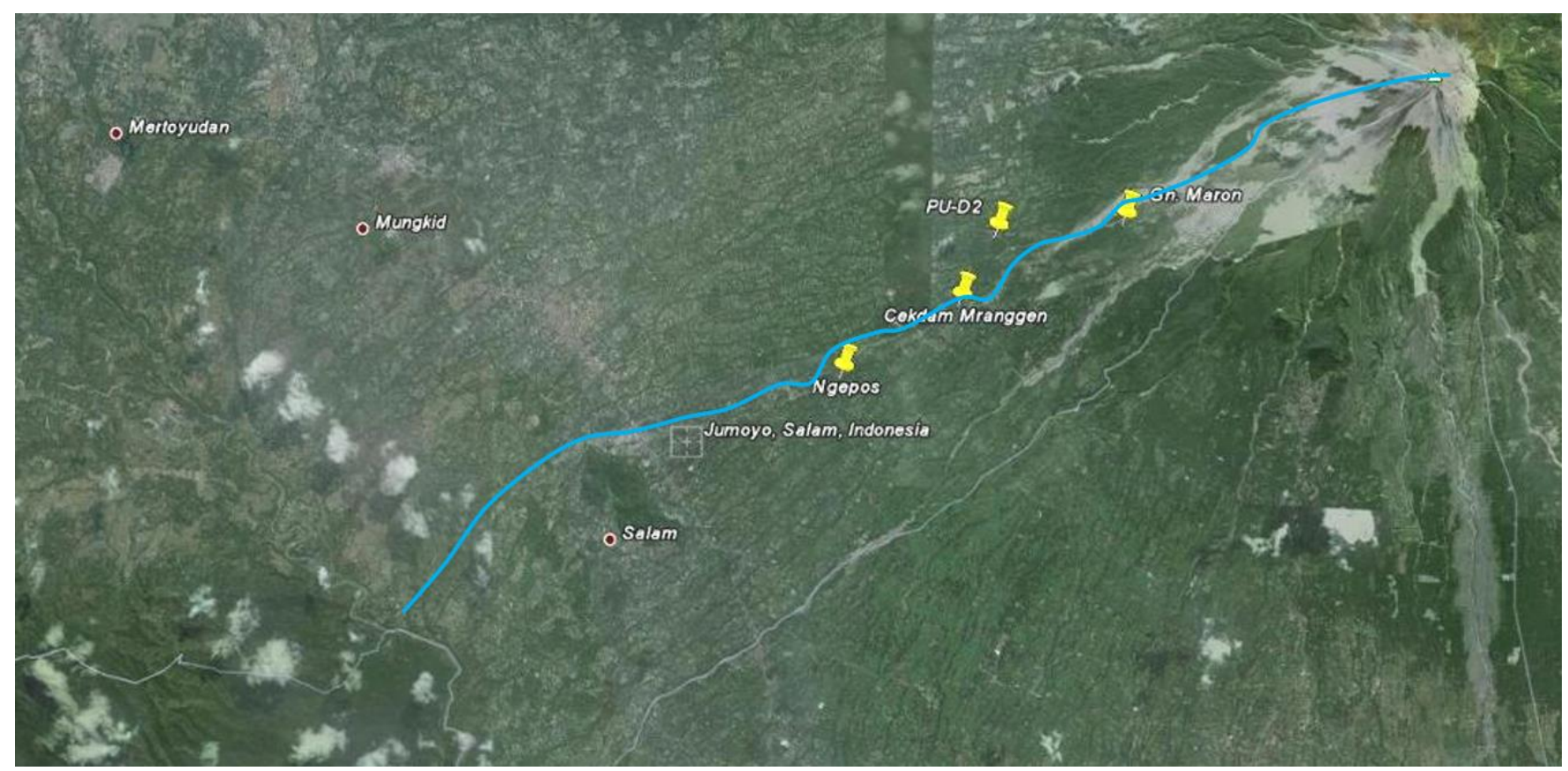

Figure 3. Location of rain stations and Mranggen Check Dam.

\section{RESULTS AND DISCUSSIONS}

\subsection{Rain Series}

In this research, collected rain series were not limited by the value of rain series $\geq 80 \mathrm{~mm}$ but it is limited by the absence of rain for 24 hours or more before or after the rain series. There were rain series with cumulative rainfall of $<80 \mathrm{~mm}$ that showed the occurrence of lahar flow (Gonda, et al., 2013). Cumulative Rain Series $<80$ $\mathrm{mm}$ can be seen on Table 2. There are 2 (two) possibilities of the reason why the rain series in Ngepos Station has lower cumulative rainfall but encountered lahar flow disaster, i.e.:

a) The rain series in Ngepos Station was small but the rainfall at the deposit area (upstream) has higher rain series

b) If the station in the deposit area (upstream) at that time also has rain series with lower cumulative rainfall then the lahar flow occurrence might be caused by of ejected volcanic eruption. The volcanic ashes can be easily eroded by the flow on the surface even though with lower rainfall (Cahyono, 2012). This kind of lahar flow is classified as mud debris flow which usually occurs approximately 3 months after the eruption.

Cumulative rainfall in Ngepos Station cannot be confirmed to trigger lahar flow since there is no data from PU-D2 and Gunung Maron Stations at the same time to support the prediction (see Table 2).
Table 2. Rainfall $<80 \mathrm{~mm}$

\begin{tabular}{llllll}
\hline Station & $\begin{array}{l}\text { Lahar } \\
\text { Flow } \\
\text { Occur } \\
\text { rence }\end{array}$ & From & Until & $\begin{array}{l}\text { Series } \\
(\mathrm{mm})\end{array}$ & $\begin{array}{l}\text { Working } \\
\text { Rainfall } \\
\text { before } \\
\text { Lahar } \\
\text { Flow } \\
(\mathrm{mm})\end{array}$ \\
\hline G. & $3 / 12 / 2$ & $2 / 12 /$ & $3 / 12 /$ & 77 & 82.52 \\
Maron & 012 & 2011 & 2012 & & \\
PU-D2 & $3 / 12 / 2$ & $1 / 12 /$ & $3 / 12 /$ & 69.8 & 75.72 \\
& 012 & 2011 & 2012 & & \\
Ngepos & $23 / 12 /$ & $22 / 12$ & $23 / 12$ & 37.5 & 9.07 \\
& 2010 & $/ 2010$ & $/ 2010$ & & \\
Ngepos & $15 / 01 /$ & $14 / 01$ & $18 / 01$ & 42.5 & 2.42 \\
& 2011 & $/ 2011$ & $/ 2011$ & & \\
Ngepos & $16 / 01 /$ & $14 / 01$ & $18 / 01$ & 42.5 & 26.92 \\
& 2011 & $/ 2011$ & $/ 2011$ & & \\
Ngepos & $17 / 01 /$ & $14 / 01$ & $18 / 01$ & 42.5 & 33.92 \\
& 2011 & $/ 2011$ & $/ 2011$ & & \\
Ngepos & $19 / 02 /$ & $19 / 02$ & $20 / 02$ & 39.5 & 38.95 \\
& 2011 & $/ 2011$ & $/ 2011$ & & \\
\hline
\end{tabular}

4.2 Result of Rain Intensities and Working Rainfall Graphic Plotting

This research used 3 (three) rainfall stations of which data were calculated based on Equation1 and Equation 2, compared, and determined which station is eligible for the further analysis. Correlation between rainfall intensity and working rainfall of rainfall stations are depicted from Figure 4 thru Figure 7. 


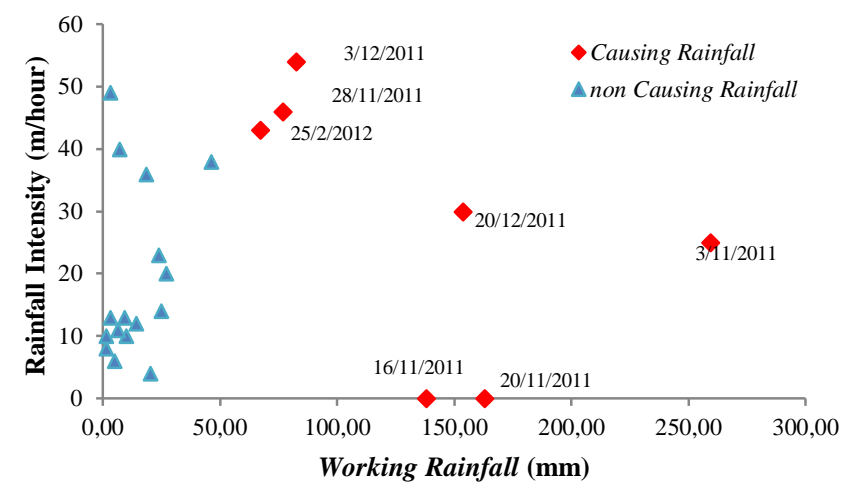

Figure 4. Correlation between rainfall intensity and working rainfall at Gunung Maron Station.

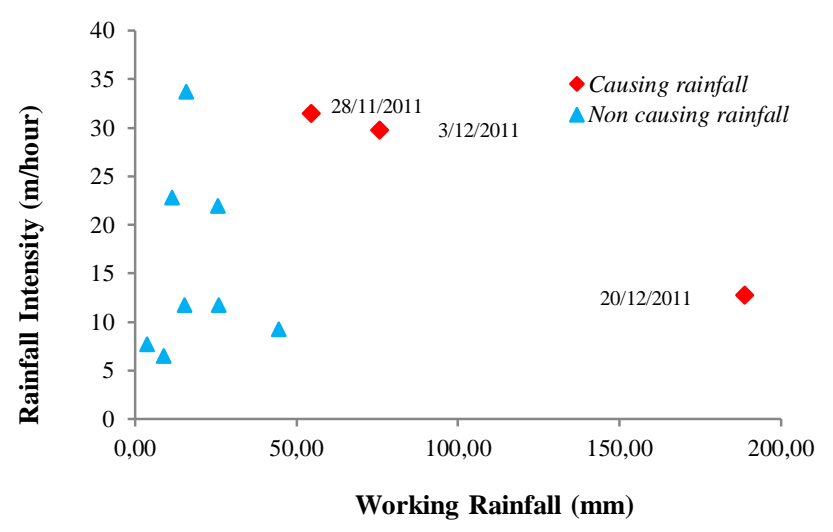

Figure 5. Correlation between rainfall intensity and working rainfall at PU-D2 Station.

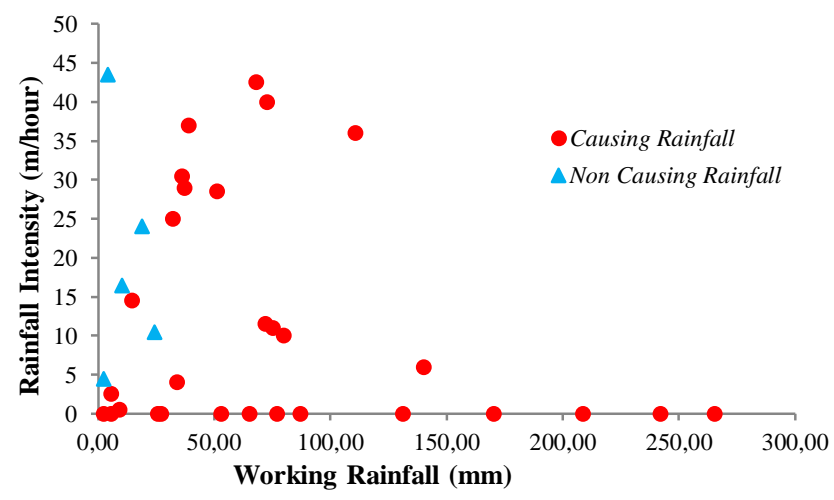

Figure 6. Correlation between rainfall intensity and working rainfall at Ngepos Station.

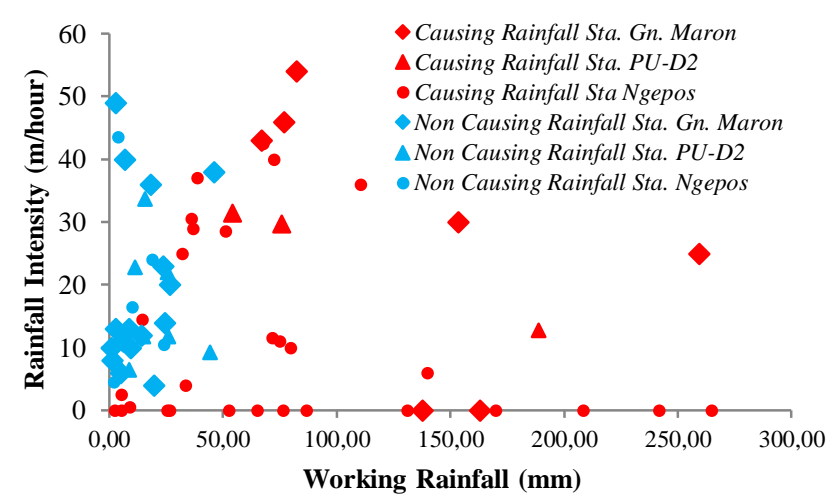

Figure 7. Correlation between rainfall intensity and working rainfall at Gunung Maron, PU-D2, and Ngepos Station.

\subsection{Result of WL, EL, CL Plotting}

Gunung Maron Station was selected for lahar flow warning criteria in Putih River since:

a) This station is located at the most upstream area and there were deposited sediments.

b) PU-D2 station did not have enough data. Rainfall data from PU-D2 station with Gunung Maron Station did not have any correlation value as well. Hourly rainfall data comparison between PU-D2 and Gunung Maron Stations had a range value of 0.8-1.2 (see Table 3) while the average frequency of rainfall intensity that may cause lahar flow was $15 \%$ which make the correlation between both data station is quite small. However, it can be observed that the rainfall frequency at Gunung Maron station is $83 \%$ higher than PU-D2 station for each month.

c) Rainfall data from Ngepos Station is difficult to generate a CL line due to the low working rainfall value in the case of causing rainfall data, as well as there is no convincing data that can predict the incident of lahar flow at Ngepos Station.

Drawing CL at Gunung Maron Station was done by crossing the CL Line on 2 points from causing rainfall data in the outer area. The line is only crossed 2 points due to limitation data quantity. From Figure 8, it can be seen that standard rainfall for warning (R1) is $22 \mathrm{~mm}$, RH2M-RH1M is $27 \mathrm{~mm}$, while standard rainfall for evacuation (R2) is $49 \mathrm{~mm}$

Table 3. The value comparison between rainfall intensity and working rainfall before lahar flow occurrence in Sta. Gunung Maron and PU-D2

\begin{tabular}{llllllll}
\hline \multirow{2}{*}{ No. } & Date & \multicolumn{2}{l}{ Sta. Gunung Maron } & Sta. PU-D2 & & \multicolumn{2}{l}{ Ratio } \\
\cline { 3 - 8 } & & $\begin{array}{l}\text { Working } \\
\text { Rainfall }(\mathrm{mm})\end{array}$ & $\begin{array}{l}\text { Rainfall Intensity } \\
(\mathrm{mm} / \text { hour})\end{array}$ & $\begin{array}{l}\text { Working } \\
\text { Rainfall }(\mathrm{mm})\end{array}$ & $\begin{array}{l}\text { Rainfall Intensity } \\
(\mathrm{mm} / \mathrm{hour})\end{array}$ & $\begin{array}{l}\text { Working } \\
\text { Rainfall }\end{array}$ & $\begin{array}{l}\text { Rainfall } \\
\text { Intensity }\end{array}$ \\
\hline 1 & $28 / 11 / 2011$ & 104 & 30 & 54.37 & 31.5 & 1.91 & 0.95 \\
2 & $3 / 12 / 2011$ & 82.52 & 54 & 75.72 & 29.8 & 1.09 & 1.81 \\
3 & $20 / 12 / 2011$ & 153.76 & 30 & 188.68 & 107 & 0.81 & 0.28 \\
\hline
\end{tabular}




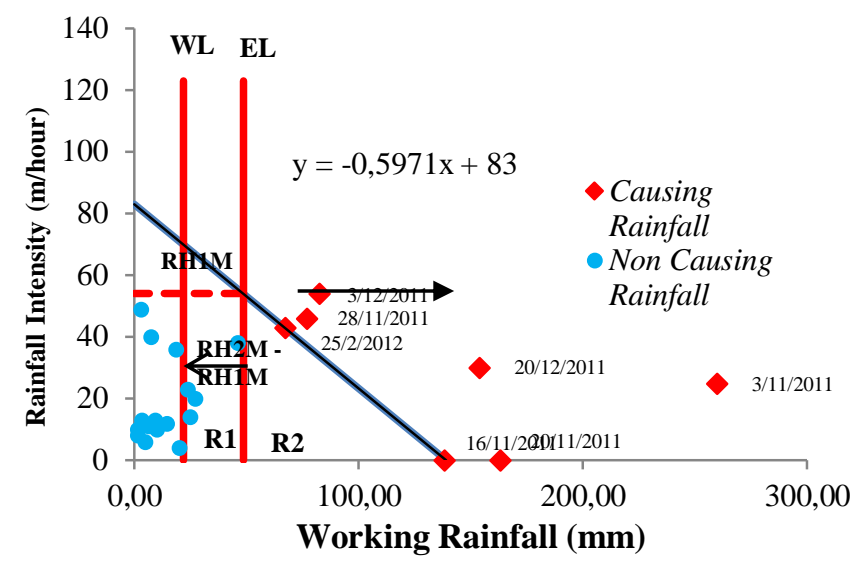

Figure 8. Plotting warning line, evacuation line and critical line, Gunung Maron rainfall data.

\subsection{Result of Plotting and Snake Line Evaluation}

An example of snake line plotting at Gunung Maron Station can be seen in Figure 9.

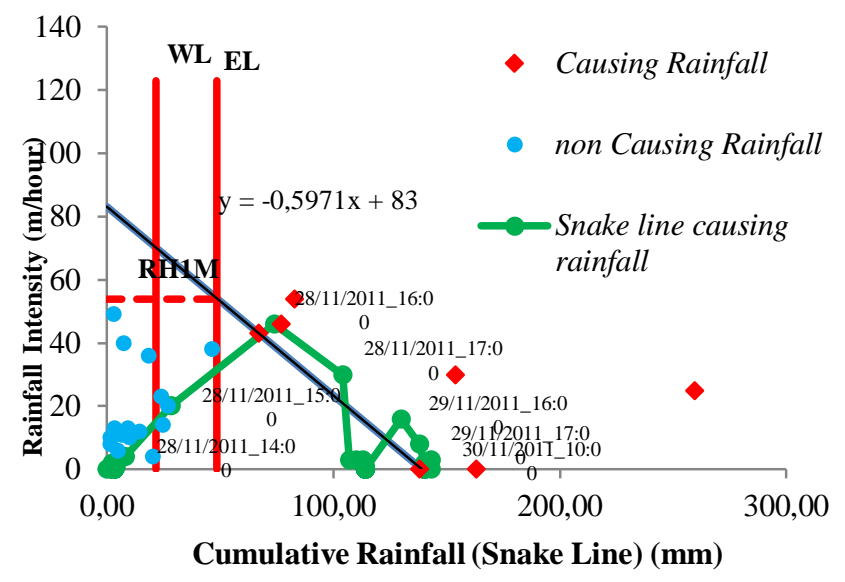

Figure 9. Snake line rain series on 27-30 November 2011 Gunung Maron Station.
From Figure 9, there were 2 evaluation categories as follows:

a) Causing rainfall data value is specified 1 if it crosses the line and 0 if it does not cross the line, meanwhile, for non-causing rainfall data, a score of 1 is given if it does not cross the line and 0 if it crosses the line. An accuracy score obtained for the warning line (WL) was $30 \%$, evacuation line (EL) was $61 \%$, and critical line (CL) was $83 \%$,

b) Score of 1 is given if the causing rainfall data of the snake line crosses the line and non-causing rainfall data and the snake line both crosses and not crossing the line, while it becomes 0 if the causing rainfall data and snake line do not cross the line with an accuracy score for warning standard (WL) as much as $100 \%$, evacuation line (EL) $100 \%$, and critical line (CL) $96 \%$.

The accuracy score of WL and EL is deemed not significant, this is the weakness of Method A. The standard rainfall determined by the method can be easily achieved during a long duration time of rainfall or intermittent rains. From the plotting of snake line, a causing rainfall data is below the borderline or indicates safe zone, yet there was a lahar flow occurrence. This was because in plotting the snake line, the antecedent rainfall was not included while in determining the warning criteria it is included. Thus, to determine the warning criteria and plot the snake line, the antecedent rainfall should be included since to ensure the safety of the community. The characteristics of the snake line in Putih River can be seen in the following Figure 10. The snake line is causing the lahar flow to form a relatively similar angle that is between $40^{\circ}$ to $45^{\circ}$, with snake line slope average of $42,5^{\circ}$ (Figure 10).

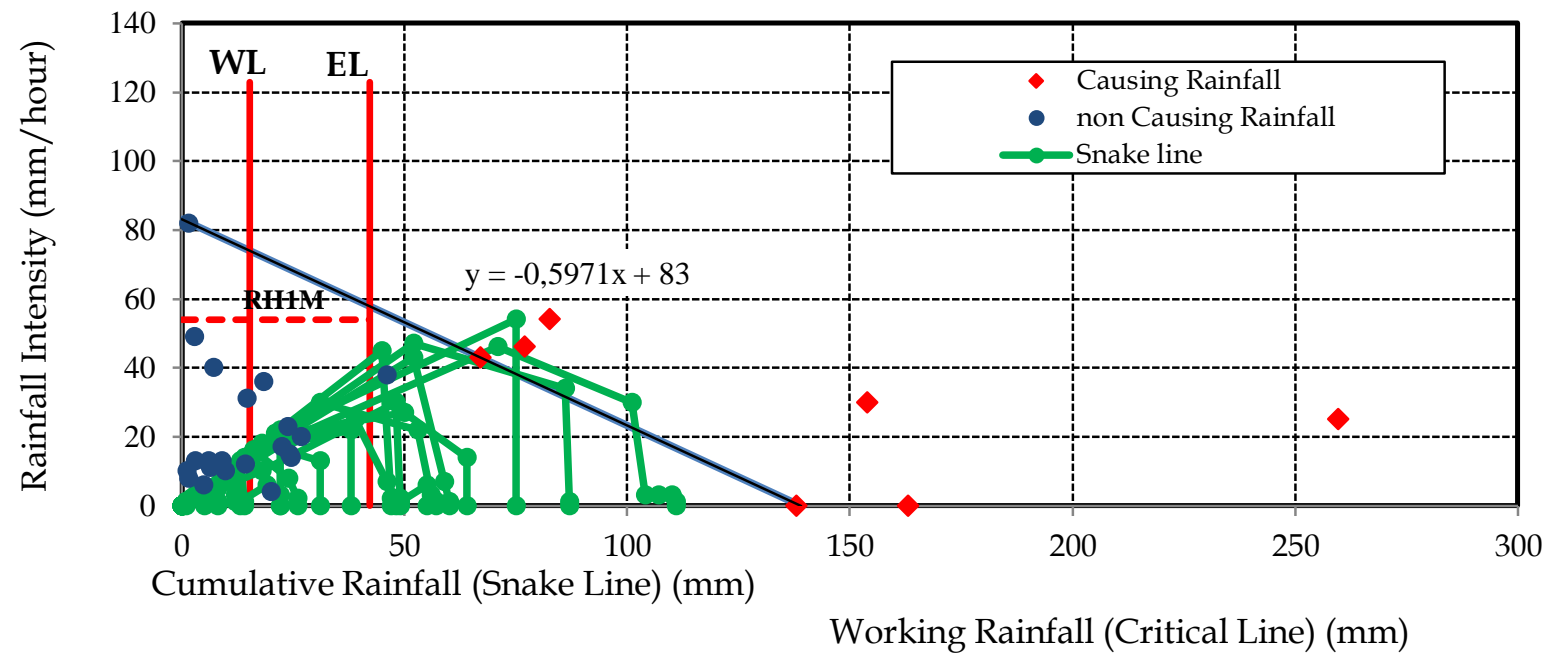

Figure 10. Snake Line Characteristic in Putih River. 


\section{CONCLUSIONS AND RECOMMENDATIONS}

\subsection{Conclusions}

From the results, some conclusions can be drawn as follows:

a) Based on the rainfall data recorded at Gunung Maron Station and historical data of lahar flow occurrence, a critical line can be drawn which gives the standard value of rainfall for warning at $22 \mathrm{~mm}$ and the standard value of rainfall for evacuation at $49 \mathrm{~mm}$.

b) The behavior of snake line which causes the lahar flow in Putih River performs an angle between $40^{\circ}$ up to $45^{\circ}$, there were some inconsistencies regarding created evacuation and warning line.

c) Compatibility of snake line towards warning criteria and evacuation are $30 \%$ for warning line, and $61 \%$ for evacuation line, and $83 \%$ for the critical line.

d) There were some non-causing rainfall data on snake line drawing that crosses the warning and evacuation line. It shows the weakness of Method A in which standard rainfall determined by the method can be easily achieved during a long duration period of rainfall or intermittent rains.

\subsection{Recommendations}

Hereby some recommendations necessary to consider in further research:

a) Further research with longer rainfall data is required to enhance the certainty of generated critical line.

b) Rainfall occurs beyond watershed area may contribute the lahar flow occurrences in Putih River, so that it is necessary to consider in the calculation.

c) Development of early warning criteria with other methods accommodating soil humidity such as the committee method is needed.

d) Investigation of the deduction coefficient used in the antecedent rainfall calculation corresponding how big is the influence of the days before the rain series towards soil humidity should be conducted.

e) The plotting of snake line should be done by considering the antecedent rainfall.

\section{REFERENCES}

Cahyono, J., 2012. Penanggulangan Daya Rusak Aliran Debris, ebook dan free download [Reduction of Destruction Force Caused by Debris Flow]. [Online]
Available at: www.jcpoweryogyakarta.blogspot.com [Accessed 12 September 2013].

Gonda, Y., Legono, D. \& Santosa, U. B., 2013. Debris Flow and Flash Floods after the 2010 Eruption of Mt. Merapi, Indonesia. Yogyakarta.

Ministry of Land, Infrastructure, and Transport (MLIT), 2004. Guidelines for Construction Technology Transfer, Development of Warning and Evacuation System against Sediment Disaster in Developing Countries. Infrastructure Development Institute, Japan.

Ministry of Public Works, 2012. Manual for Preparation of Early Warning and Evacuation System for Flash Flood, Jakarta. 